\title{
Reasoning Scaffold Model for Instructional Simulation Development and Application $^{*}$
}

\author{
Habibe ALDAĞ ${ }^{a^{*}}$, Ahmet DOĞANAY ${ }^{a}$, Lütfiye Sema KÖROĞLU-ULUTAŞ ${ }^{b}$ \\ ${ }^{a}$ Çukurova Üniversitesi, Eğitim Fakültesi, Adana/Türkiye \\ ${ }^{b}$ Bayraktar Anadolu Lisesi, Gaziantep/Türkiye
}

\section{Article Info}

DOI: 10.14812/cufej.2015.008

Article history:

Received 21 December 2014

Revised 21 February 2015

Accepted 25 March 2015

Keywords:

Scientific discovery learning,

Concept learning,

Toulmin Argumentation Model,

Reasoning scaffold,

Question prompt

Simulation

\begin{abstract}
Numerous studies have been carried out in computer-mediated and computersupported learning environments. They have reported the effectiveness of scaffolding strategies for engaging students in the learning process. These studies in variety of subjects such as economics, mathematics have focused mostly on developing illstructured problem solving, decision making, and critical thinking skills and rarely on argumentation skills. On the other hand, concept attainment is discussed and studied intensively from various theoretical perspectives for more than 50 years. Theory-based concept learning claims that people understand and explain new situations based on their prior experience which has resemblance to a theory in itself. It is compatible with constructivist approaches. For a basic 8th Grade Genetic Simulation, a scaffolding model is developed according to the theory-based concept view and scientific discovery learning. Toulmin argumentation model as scaffolding strategy is functionalized by Socratic questioning technique to engage learner in analysis and reflection in a simulated concept learning environment. In this paper, the model for scaffolded simulation and the development process are explained. The issues arising from a successful application study of simulation model are presented.
\end{abstract}

\section{Öğretimsel Simulasyonlar için Akıl Yürütme Desteği Modeli: Tasarım, Geliştirme ve Uygulama}

\section{Makale Bilgisi}

DOI: $10.14812 /$ cufej.2015.008

\section{Makale Geçmişi:}

Geliş 21 Aralık 2014

Düzeltme 21 Şubat 2015

Kabul 25 Mart 2015

Anahtar Kelimeler:

Buluş yoluyla öğrenme

Kavram Öğrenme

Toulmin Tartışma Modeli

Akıl yürütme destekleri

Simulasyon

Benzetim

\section{Öz}

Bilgisayar destekli öğretim çevrelerinde yeni destekleme stratejileri ile yapılan çalışmaların etkili olduğu görülmektedir. Bu çalışmalar genellikle ekonomi veya matematik gibi alanlarda iyi-yapılandırımamış problem çözümleri, karar verme ve eleştirel düşünme üzerine yapılmıştır. Tartışma kuramın destekleme stratejileri ile ilişkilendirildiği bilgisayar destekli çalışmaların sayısı fazla değildir. Bunun yanında kavram öğretimi en az 50 yıldır farkı kuramsal yaklaşımlar ile çalışıımışır. Kuram temelli kavram öğrenme bireyin kendine-özgü bilgi ve deneyimler temelinde olayları ilişkilendirdiğini veya açıkladığı savunmaktadır. Geleneksel öğretim tasarımı yaklaşımları ile kıyaslanıldığında kuram-temelli kavram öğrenme, yapıcı öğrenme yaklaşımı ile daha uyumlu görünmektedir. Bu ilke temelinde 8. Sınıf genetic ünitesindeki kavramların buluş yoluyla öğretimi için bir simulasyon modeli geliştirilmiş ve uygulanmışıı. Tartışma Modeli, öğrencinin inceleme ve yansıtma davranışlarını harekete geçirme amacıyla destek stratejisi olarak kullanıımışır. Toulmin'in Tartışma modeli sokratik sorgulama tekniği ile buluşa destek yapı olarak ișlevselleștirilmiștir. Bu çalışmada geliştirilen akıl yürütme-destekli simulasyon modeli ve modelin işleyiş süreci tanıtılacaktır.

\footnotetext{
* Reasoning scaffold model applied in a master thesis by Köroğlu (2009). Bu çalışmada sunulmuş olan destek model, Köroğlu (2009) master çalışmasında uygulanmıştır.

Yazar: haldag@cu.edu.tr
} 


\section{Introduction}

The basic criterion of efficient and effective instructional design is ensuring the consistency among content structure, learning goals, teaching process, instructional material and evaluation. Students' success depends on the consistency of these instructional elements. Ministry of Turkish Education (MTE) is accepted new program grounded on constructivism at 2004 as a part of Bologna process. However, process of adaptation is a difficult one. The struggle of teachers as well as students are continuing. Even teachers who have appropriate conceptual models of constructivism and have a positive attitude toward the new system are having difficulty to implement the program without proper instructional material and evaluation tools. Instructional technologists who are skillfull in computer science do not know how to develop computer software in alignment with goals, processes, and evaluation techniques of constructivist approach. To satisfy that need we first developed a reasoning scaffold model for instructional simulation. Model is compatible with concept learning based on scientific discovery learning approach. It is applied in a master thesis by Köroğlu (2009). She developed a a simulation software for 8th grade genetic unit and run a pilot study and an experimental study.

The reasoning scaffold model for simulation development, which is presented here, was a part of this larger study. We had two goals that we hope to accomplish in this paper: One, presenting the simulation development model in concept learning that is grounded on research findings of scientific discovery learning; second, providing an example of model application into a instructional software compatible with constructivist principles. Here, first we will discuss the theoretical basis; then, we will present the model and discuss the application results. Model in flow chart and example pages of simulation are presented at the end of the paper.

\section{Concept Formation}

Concepts are mental representations of categories of objects, events, or other entities (Jonassen, 2006). In classical view, we could characterize concepts by three elements: concept name, essential and non-essential concept attributes, and the attribute value within a concept (Joyce and Weil, 2000). Concepts might be classified as concrete and defined concepts (Gagne, Briggs and Wager, 1992). Concrete concepts are known by their physical properties. Defined concept has a rule that classifies objects or events (1992). A rule expresses the relationships among the concept's attributes and its function (1992). Attribute value is the degree to which some characteristic is manifested in order to categorize a concept accurately (Joyce, Weil and Calhoun, 2000). Attribute value is critical to the identification of abstract or defined concepts (Lasley, Matczynski and Rowley, 2002). Concept can be also hierarchically classified (Gagne, Briggs and Wager, 1992); superordinate, subordinate and coordinate. Examples will have all essential attributes while non-examples will not have one or more of the essential attributes. Students will only be able to fully explore the attributes if they are given nonexamples as well as examples (Karataş-Coşkun, 2011). Above descriptions mostly favor classical instructional design approach to concept teaching.

Criticizing similarity views (attribute isolation, probabilistic) and intermediatary relational views (prototype and exemplar), Jonassen (2006) re-draw our attention to concepts as personal constructs. He argues that concepts should be learned and assessed in the context of conceptual organizations. They are fostered by the development of personal theories of the world and the conceptual change that facilitates those processes. In other words, conceptual development is personal. Each person organizes concepts personally based on their experiences. According to Jonassen (2006), actional views and theory-based views of concepts are able to account for all of the rules governing concept formation, patterns of concepts, and concepts-in-use. Concepts are represented in networks which include causal, explanatory links based on network information process theories. Personal construct theory claims that concepts can change over time, in different context and for different purposes (Kelly, 1963). Concept development based on Kelly's theory is continuous, active, personally creative process of differentiation and integration. Actional view defines concepts as active, constructive and intentional constructs. In classical concept view, a concept is an end-product of learning. Attribute categorization is emphasized 
during teaching process. On the contrary, in actional and theory based concept view, concepts are developing connections in problem solving process. Construction of relation between events and objects is emphasized during teaching process.

A teacher might follow different paths to teach concepts and generalizations for different learning behaviors. For example, Akbulut-Taş (2010) investigated implicit or explicit paths for teaching clasification and explanation of concepts and generalizations. It is also posibble to follow a deductive or inductive paths for teaching a concept (Rieber and Parmley, 1995). Deductive instructional approaches are efficacious specifically for teaching certain type of functional or procedural skills. However, they are limited in engaging student to a deeper content analysis. As a result, surface learning results with poor development of critical thinking skills in the long term. We could say that deductive approach is more applicable for classical concept view and limited in-use for actional, theory based concept view. Inductive thinking approaches to thinking have also deep, rich historical and philosophical roots in Socratic Method, over 2000 years. Lasley, Matczynski and Rowley, (2002) presented three inductive instructional approaches to concept teaching. First, concept attainment model is based largely on Bruner, Goodnow and Austin (1967) popularized as teaching strategy by Joyce, Weil and Calhoun (2000) and Eggen and Kauchak (2001). In concept attainment model, students must engage in higher-order thinking skill, move from specific examples or instances by hypothesizing and identifying essential attributes to general ideas and concepts. Second, inquiry model of concept learning requires student critically think about data that they generate themselves. Inquiry has three general stages: exploration, invention and discovery (Biben, 1980). Third, concept formation strategy gives students more space to explore their own personal ideas and perspectives.

Inductive approaches compared to deductive approaches are more compatible with actional, theory based concept view, consequently with the constructivist learning strategies. However, students specifically with low ability and/or low self-esteem may have difficulty in unguided discovery learning environments. In this case, teacher may utilize first guided discovery, then, may fade into an unguided inquiry to create cognitive conflict, to support conceptual development and to foster creativity. At this point, a primary concern should be given to model selection. The model must be appropriate for providing the consistency among content structure, learning goals, teaching process, instructional material and evaluation. Toulmin argumentation model is used as scaffolding constructs for learning and assessment.

\section{Toulmin Model of Argumentation}

Toulmin suggests that Aristotelian logic with mathematical syllogisms simply doesn't fit for the daily arguments. Claiming that theoretical argument is irrelevant to the assessment of practical argument, he distinguishes between practical and analytic arguments (Toulmin, 1958). In analytic arguments, arguers ground their claims on abstract, unchanging and universal principles. Thus, the conclusion of an analytic argument such as "Socrates is mortal" is limited only with the premises of "All human are mortal" and "Socrates is a human.". Our interest in analyzing argument in traditional logic is to decide whether we have a valid argument or not on the basis of premises.

Different from analytic arguments, arguers ground their claims in the context of a particular situation in practical arguments. A practical argument involves mostly an inference from some data to the conclusion of the argument. While arguer implicitly states warrant, audience have to consider how warrant applies to this inference. Therefore, we do not limit our arguments to universally acceptable knowledge, rules or conclusions. On the contrary, we even use our beliefs, assumptions, opinions or the conditions of that particular situation to make a decision on how reliable the argument is. Kelly's (1963) personal construct theory is consistent with this view. George Kelly was interested in helping people categorize experiences and classify their environment. George Kelly's (1955) theory of a personal scientist was that each individual seeks to predict and control events by forming theories, testing hypotheses, and weighing experimental evidence. Personal scientist is always building up and refining theories and models about how the world works so that he can anticipate events. These anticipations 
and predictions drive our reasoning as well as arguments. Lenat (1982) argues that knowledge representations of an individual should shift as different problem solving needs arise. A person can not only use this personal representations to predict events more accurately and to act more effectively, but he/she can also change these representations to fit specific perceived needs (Shaw, 1981). Conceptual development (or the term construct) is personal, continuous, active, creative process of differentiation and integration (Kelly, 1963). Toulmin's and Kelly's theories share similar assumptions of personally constructed meanings, changing meanings over time, in different context and for different purposes.

In school, even if students are explicitly taught about the universally valid rules or relations; they continue to construct their understanding based on their prior knowledge, daily experiences and their needs. Students do not mostly generate hypothesis on universal rules. They do not compare objectively their hypothesis against experiment results or assess analytically their reasoning for valid arguments. Indeed, students generate hypothesis, weigh evidence on the basis of their personal theories and purposes. As a result, in school life we counter not with the valid or invalid arguments, but with more or less reliable argument on which we could decide to some extent. As a result, Toulmin's model of argumentation is an appropriate tool for teaching or assessing scientific discovery learning behaviors in constructivist learning environment. Also it is more compatible for assesment of personally constructed conceptual schemes.

Argumentation as a form of informal reasoning requires students to identify various alternative perspectives or opinions; to develop or to select a reasonable solution; to make a decision on the basis of warrant; to support his/her preferred solution or decision with the appropriate evidence related to context (Toulmin, 1958). Toulmin's model of argumentation has six interactive components: Claim, data and warrant are primary; backing, rebuttal and qualification are secondary parts of the model (Toulmin, 1958; Toulmin, Reieke, ve Janik, 1984). Argumentation structures in Toulmin's model are field independent, functional components; however, conditions which must be defined in the context of particular argumentation imply the field dependent side of argument. The model with field dependent and indepent quality still is one of the most influential theory of argumentation (Driver, Leach, Millar and Scott, 1996; Kelly, Druker and Chen, 1998; Russell, 1983; Yerrick, 2000). Although, the model is criticized for its shortcomings (Aldağ, 2006a; Driver, Newton, and Osborne, 2000; Duschl, Ellenbogen, and Erduran, 1997; Van Eemeren, Grootendorst, Henkemans, Blair et. al., 1996). For this study, definitions of data, warrant and backing are slightly changed. Similarly relation among components are re-organized for the practical reasons. After these practical changes socratic questioning tecnique applied to the Toulmin model components to transform them to scaffolding structures for guided inquiry which will be embedded in the simulation environment. Now, scaffolding concept will be introduced.

\section{Tools for Scaffolding}

In guided discovery learning, a teacher may use Socratic questioning technique to support student inquiry. Questioning would be practiced first by teacher then by students. Thus, students would develop scientific discovery skills in addition to constructing concepts in inductive learning environments. Supporting student learning with Socratic questions might be a part of solution to students' learning difficulties. It is also very compatible with the original notion of scaffolding. Zone of proximal development (a concept of sociocultural theory of Vygotsky) refer to the distance between the child's actual developmental level as determined by independent problem solving and the higher level of potential development as determined through problem solving under adult guidance or in collaboration with more capable peers (Wertsch, 1985). For a successful scientific discovery learning in a class, first teacher has to know the zone of each individual child; second, has to identify what kind of help that student would need about the related problem; third, has to provide that specific help in a timely manner. Teachers do not have that time because of over crowded classes. To fill in the gap, recent project-based, problem-based, and design-based constructivist approaches to learning have explored 
ways to use computer tools. For example, in EMILE (Guzdial, 1995), prompts and questions were provided by a computer tool to individuals or small groups, based on an analysis of the difficulties learners tend to have with certain concepts or activities. Other successful examples includes Knowledge Integration Environment (KIE) (Davis and Linn, 2000), Model-It (Jackson, Krajcik, \& Soloway, 1998). These software are compatible with actional, theory-based view of concept. Theory-based view of concept is in turn consistent more with the constructivist approach. Constructivists are interested in teaching complex concepts in problem solving context. Jonassen (2006) advises that conception of concepts-in-use will be more useful for advising the design of more complex and problem-centered learning environments. Conceptual change as well as cognitive conflict becomes the focus of an ongoing assessment and teaching practice. For theory building and assessment of conceptual change, various strategies is proposed in the literature: analyzing students interaction protocols (Hogan and Fisherkeller, 2000), structured interviews (Southerland, Smith, and Cummins, 2000), concept maps (Edmundson, 2000), hypertext environments (Gall and Hannafin, 1994), simulations (de Jong, 1991; Reigeluth and Schwartz, 1989) and modeling environments (diSessa and Abelson and Ploger, 1991). Scientific discovery learning in computer simulations of conceptual domain is still under study.

\section{Scientific Discovery Learning with Computer Simulation}

Discovery learning studies of Bruner (1961) is started with conceptual learning, then, gave rise to the scientific discovery learning. The main task of student in scientific discovery learning is to define a problem, state a hypothesis, design experiments, observe, collect, analyze and interpret data, apply the results and make predictions (Friedler, Nachmias, and Linn,1990).

A computer simulation environment is a computer-based application in which students can infer the characteristic of underlying model by experimenting. Simulation contains a model of a conceptional system and/or operational system (De Jong, 1991). Conceptual models display facts, concepts, principles; while, operational models display sequential operations connected with a set of consistent rules or principles. Computer simulation vary in type; static to dynamic, quantitative to qualitative, simple to complex etc.(Van Joolingen \& De Jong, 1991a; Brant, Hooper, \& Sugrue, 1991; Coleman and Randall, 1986). The learners' basic actions are changing values of input variables; then, observing the resulting changes on values of output variables (Reigeluth and Schwartz, 1989). Learner manipulates one or more variables to see the effect on other variables; by experimenting with a series of hypothesis, eventually learner is expected to discover the underlying basis of simulated model.

Theoretically, computer simulation must be the best suited constructivist learning tool which requires self-directed discovery learning. However, many studies found no difference between result of simulation-based discovery learning approach and expository teaching approach (i.e. Rivers and Vockell, 1987; Carlsen and Andre, 1992; Chambers et al., 1994). Bangert-Drowns, Kulik, and Kulik (1985) report that simulation based learning does not raise examination scores. The studies of Rieber (1990), and Rieber and Parmley (1995) are resulted in favor of tutorial teaching. However, a few study reported favorable result for simulation based learning (i.e Grimes and Willey, 1990).

De Jong and Van Joolingen (1998) reviewed research results and discussed several problems along with solutions. In this review, researchers defined the problems in the phases of hypothesis generation, experiment design and data interpretation for scientific discovery learning with computer simulations of conceptual domains. Njoo and de Jong (1993) found that engineering students had difficulty of generating hypothesis that could be a result of not knowing what a hypothesis should look like. Learners have difficulty in adapting hypotheses on the basis of data gathered (De Jong and Van Joolingen, 1998). They did not drop the original hypothesis in the face of disconfirming evidence (or otherwise) (Dunbar, 1993); they ignored anomalous data (Chinn and Brewer, 1993); avoided hypothesis which have a high possibility of rejection (Klayman and Ha, 1987; Klahr, Fay, and Dunbar, 1993; van Joolingen and de Jong, 1993). 
Quinn and Alessi (1993) found that learner have a tendency to seek for information to confirm their hypotheses (called confirmation bias). Another problem was designing inconclusive experiment by manipulating too many variables at one time (Schauble, Glaser, Raghavan, and Reiner, 1991) or by conducting experiments which had nothing to do with their hypotheses (Van Joolingen and De Jong (1991b; 1993). The subjects overlooked many important variables while experimenting several times for the same limited set of variables (Kuhn, Schauble, and Garcia-Milla, 1992). Learner experimented to create a desired result instead of understanding the conceptual model or testing the hypothesis (called engineering approach) (Schauble, et. al. 1991). When they have no problem in stating hypothesis or experimenting, they misinterpreted the data and confirmed hypothesis when it has to be rejected (Klahr, Fay and Dunbar, 1993).

In a number of studies, regulative processes defined as a responsible factor discriminating successful learner from unsuccessful learner in discovery learning (Lavoie and Good, 1988; Simmons and Lunetta, 1993; Shute and Glaser, 1990). Some of good learning behaviors of discoverer were systematic planning, monitoring, paying attention to data management, responding realistically to data result. Note taking during learning (Lavoie and Good, 1988) and more systematic data recording (Schauble et. al., 1991) were also defined as good monitoring strategies for discovery learning. Additional instructional strategies are suggested to help learners overcome the problems that they may have in phases of scientific discovery learning environment. Klahr, Fay and Dunbar (1993) suggested some principles for experiment phase of discovery learning: design simple experiments to enable easy monitoring, design experiments that give characteristic results, focus on one dimension of a hypothesis, exploit surprising results, and use the a priori strength of a hypothesis to choose an experimental strategy.

From studies that empirically examined the discovery learning process, De Jong and Van Joolingen (1998) suggested some instructional strategies to support learners for successful discovery learning:

- Providing direct access to domain information synchronously with the simulation so that the information is available at the appropriate moment.

- Providing learners with assignments (or questions, exercises, or games) to have a clear effect on the learning outcome (embedded in simulation)

- Model progression: Using model progression for complex phenomenon

- Structuring the environment with the combination of other strategies.

For other individual strategies they concluded the evidence is not substantial enough to warrant general conclusions (e.g., hypothesis support, experimentation hints, monitoring tools, prediction support).

\section{Design Process}

The general structures used for this study will be mentioned first. Toulmin Argumentation Model structures are claim, data, warrant, warrant support, qualifier and rebuttal (Toulmin, 1958). Content structures are concept label, attributes, examples. The main task of student in scientific discovery learning is to define a problem, state a hypothesis, design experiments, observe, collect, analyze and interpret data, apply the results and make predictions (Friedler, Nachmias, and Linn,1990). Now we will explain how we used Toulmin argumentation structures as scaffolding strategy to engage learning and reflection in simulated concept learning environment. Toulmin argumentation model is selected as reasoning scaffolds for scientific discovery learning simulation environment. Its'context independent quality makes the model appropriate as scaffold structures for variety of subjects. Toulmin Argumentation model is utilized as coding scheme structure in content analysis (Lunsford, 2002) and as support system for context independent argumentation software in ill-structured problem solving (Tan, 2000; Cho, 2001; Carr, 1999; Gee and Land, 2004). 
In first stage of scaffold design process, classical concept structures are described in terms of Toulmin argumentation structures to create a compatible basis with the actional, theory-based concept view. Similarly relation flow among argument components are re-organized in accordance with scientific discovery learning processes. Redefined constructs are qualifier, data and warrant and warrant support components of the model. A qualifier is a statement about how strong the claim is. These statements limit the strength of the argument display the conditions under which the argument is true. Arguments may thus range from strong assertions to rather uncertain kinds of statement. A qualifier may include words such as 'most', 'usually', 'always' or 'sometimes'. For example if you are claiming that cancer (CA) is caused by smoking cigarettes; you might state that smoking cigarettes is the most significant cause of CA. However, we are not always explicitly setting the conditions or stating argument limits with specific words (Aldağ, 2006a). Indeed listening to one's argument, we make a decision about reliability of that argument under the effect of variety of conditions or criterions. For that reason the qualifier is described as consistency among statements and argument structures and correctness of information. Qualifier is assessed as separate argument structure labeled as consistency component. Levels of consistency also indicate the possible misconceptions. Researchers defined data as example of concepts, situation, and particular examples of the phenomenon at hand for example nursing plants, identical twins case (examples are given below). Warrant support as principles or attributes of concepts in content structures such as "change in genetic material". Warrant defined as reasoning, the relation that tied warrant support to the claim. Warrant represents the causal connections between concepts or concept attributes. For example "Genetic changes... in the case of...evidencing that...". Warrant can be exhibited explicitly or referred implicitly. Thus model becomes more compatible with theory based concept view. Rebuttal structure refers to controversial side of issues, thus making the model a flexible learning support tool for collaborative argumentation as well as monolithic reasoning.

Reasoning is a fundamental process for understanding, explanation, argumentation, consequently learning. Socratic questioning is a technique used in scientific discovery learning. In second stage of scaffold design, socratic questioning tecnique applied to the Toulmin model to transform the structures to guided inquiry scaffolding structures. The result of this transformation was the inquiry process statement and question prompts (Question scaffolds are embedded in simulation to provide timely support to each individual student during scientific inquiry process for fostering conceptual change (Figure2a,b,c ). Question prompts guide elaborative reasoning for complex theory-based concept learning. Question prompts facilitate learners' observation, classification, generalizing, comparingcontrasting and integrating towards concept formation (Ge and Land, 2004). They are also triggers for instructional reflections. Theory-based concept view is a new development compatible more with constructivist approaches to learning than classical instructional design theories. Simulation with no learning support has also risk of creation of these misconceptions (Hannafin ve Land, 2000). Below a simple example displays the trigger-reflect relation of question prompts.

CASE: Seeds are planted in lightened environment. They became a nursing plant with green leaves. These are taken into a dark place and their green leaves turn into yellow. Then, they had been taken back in to the lightened environment.

Question prompt:What happened? What is the cause of that? (Analyzing Data-Examples)

Student response: Light.

Question prompt: Can you explain that?(PresentingData-Examples)

Student response: More light more green. Lightened environment makes the plant leaves greener.

Question prompt: What result did you have after running the simulation?(Elaborating on DataExamples)

Student response: Plant's exposure to the light increased the chlorophyll and increase in chlorophyll made the green leaves darker. It seems there is a connection between light and chlorophyll and plant color. 
Question prompt: Is there a difference between your original opinion and the one after running the simulation? (Comparing and looking for rebuttal- Checking for misconception)

Student response: Yes

Question prompt: Could you explain it further? (Integrating)

Student response: One will increase the other will increase or one will decrease and the other will decrease. This is depends on the exposure to the light. It is not hereditary; it is not about genetic mutation.

Macro processes followed in simulation are (sequentially): Providing students with examples of concepts, predictions of students about the given situations in a trial, examining simulation, reasoning in the simulated situation, discussion of alternative results (comparison original hypothesis and data), defining attributes (adjusting hypothesis if necessary), presenting solutions in a written form (forming grounded argument as evidence of conceptual understanding), whole in-class discussion (defending conceptual understanding). Content and questioned prompts are combined in a genetic unit software. In addition a rubric developed for coding/evaluation purpose based on the same model. Another word Toulmin argumentation model is used during content analysis and learning process, in instructional simulation and for evaluation. Thereby, Toulmin argumentation model is utilized for establishing consistency among learning goals, instructional process, evaluation and learning tools for effective and efficient learning. Below Table1 shows combination of teaching strategies, discovery processes and scaffolded actions in structured simulation.

Genetic Unit for the 8th grade of middle school is selected for model application because of common misconceptions mentioned in literature (Schonfeld, 2000; Ferrari and Chi, 1998). The concept labels of adaptation, mutation etc. in Turkish is also creating confusion for student to understand the topic. However, these labels are well-established concept labels in the field so labels are kept as they are. Related books, journal, simulations, articles etc. searched extensively. Turkish Ministry of Education Instructional Program is examined for a beginning of instructional analysis of the unit. First classical instructional analysis phases followed by researchers to deeply analyze and understand the topic since they are not an expert in area. Tennyson and Park model (1980), Merill Component Display Theory (Merill, 1983), and Gagne learning hierarchy considered during design process. Concept map prepared to reveal the dynamic relationship between concepts of the unit. The concept definitions, critical attributes, and examples are selected, the divergency and difficulty level among examples of the concept are described. The taxonomical structure of the content is defined. Misconceptions are carefully listed and considered during whole design process. Beside possible causes of misconceptions are specified, and precautions are built in design. The meticulous/detailed process is undertaken to make sure that content is analyzed thoroughly. Content text is prepared, simulation developed and applied in an experimental study by Köroğlu (2009). Two experts in Science and Technology evaluated the whole process of design and application because researchers are not experts in genetic field but expert in instructional design. After pilot study, refinements in simulation and rubric are made for the real study. 
Table 1.

Reasoning Scaffold Model for Instructional Simulation Development and Application

\begin{tabular}{|c|c|c|c|c|}
\hline Software Structure & Students Reasoning & Discovery Process & Concept Structures & Toulmin Model \\
\hline $\begin{array}{l}\text { Providing students } \\
\text { with a problem } \\
\text { situation in text } \\
\text { form, add visuals } \\
\text { when available }\end{array}$ & $\begin{array}{l}\text { Reading, recognizing } \\
\text { and understanding } \\
\text { what is happening or } \\
\text { not happening in } \\
\text { situation }\end{array}$ & $\begin{array}{l}\text { Defining a } \\
\text { problem }\end{array}$ & $\begin{array}{l}\text { An example or non- } \\
\text { example of abstract } \\
\text { concept }\end{array}$ & Presenting data \\
\hline $\begin{array}{l}\text { Questioning } \\
\text { student about the } \\
\text { causal-correlative } \\
\text { factors }\end{array}$ & $\begin{array}{l}\text { Predictions of } \\
\text { students about the } \\
\text { given situations } \\
\text { before conducting a } \\
\text { trial }\end{array}$ & State a hypothesis & $\begin{array}{l}\text { Predicting related } \\
\text { concept or essential } \\
\text { attributes of concepts } \\
\text { in the context of } \\
\text { example }\end{array}$ & $\begin{array}{l}\text { Identifying } \\
\text { related warrant } \\
\text { support in the } \\
\text { context of data } \\
\text { toward (sub-) } \\
\text { claim }\end{array}$ \\
\hline $\begin{array}{l}\text { Presenting } \\
\text { simulations }\end{array}$ & $\begin{array}{l}\text { Analyze simulation } \\
\text { for manipulated } \\
\text { variables effect }\end{array}$ & $\begin{array}{l}\text { Design } \\
\text { experiment, } \\
\text { Manipulate } \\
\text { variables }\end{array}$ & $\begin{array}{l}\text { Manipulating } \\
\text { variables in an } \\
\text { example situation }\end{array}$ & $\begin{array}{l}\text { Manipulating } \\
\text { variables in data }\end{array}$ \\
\hline Running simulation & $\begin{array}{l}\text { Taking notes on } \\
\text { experiment }\end{array}$ & $\begin{array}{l}\text { Observe } \\
\text { Collect } \\
\text { Analyze }\end{array}$ & $\begin{array}{l}\text { Defining example or } \\
\text { non-example toward } \\
\text { result }\end{array}$ & $\begin{array}{l}\text { Defining } \\
\text { supporting data } \\
\text { or rebuttal } \\
\text { toward claim }\end{array}$ \\
\hline $\begin{array}{l}\text { Questioning to } \\
\text { define difference in } \\
\text { the original and } \\
\text { alternative opinion }\end{array}$ & $\begin{array}{l}\text { Comparison of } \\
\text { original hypothesis } \\
\text { and observation } \\
\text { results }\end{array}$ & Interpret & $\begin{array}{l}\text { Recognize possible } \\
\text { misconceptions, } \\
\text { cognitive conflict or } \\
\text { unrelated features }\end{array}$ & $\begin{array}{l}\text { Recognize } \\
\text { possible rebuttal, } \\
\text { analyze for } \\
\text { inconsistencies }\end{array}$ \\
\hline $\begin{array}{l}\text { Asking further } \\
\text { explanation } \\
\text { between } \\
\text { differences or } \\
\text { similarities between }\end{array}$ & $\begin{array}{l}\text { Adjusting or } \\
\text { transforming original } \\
\text { hypothesis into a new } \\
\text { if necessary }\end{array}$ & Interpret & $\begin{array}{l}\text { Clear reasoning to } \\
\text { construct coherent } \\
\text { conceptual model }\end{array}$ & $\begin{array}{l}\text { Controlling for } \\
\text { rebuttal, } \\
\text { readjusting data- } \\
\text { warrant support } \\
\text { claim link by } \\
\text { reasoning }\end{array}$ \\
\hline $\begin{array}{l}\text { Presenting solutions } \\
\text { in a written form } \\
\text { about original and } \\
\text { alternative opinion }\end{array}$ & $\begin{array}{l}\text { Reaching a solution, } \\
\text { grounding conceptual } \\
\text { understanding }\end{array}$ & Interpret & $\begin{array}{l}\text { Reach equilibrium: a } \\
\text { (partly) coherent } \\
\text { conceptual model on } \\
\text { issue }\end{array}$ & $\begin{array}{l}\text { Establish a strong } \\
\text { subclaim: data, } \\
\text { warrant support }\end{array}$ \\
\hline $\begin{array}{c}\text { Whole in-class } \\
\text { discussion }\end{array}$ & $\begin{array}{l}\text { Defending conceptual } \\
\text { understanding }\end{array}$ & $\begin{array}{l}\text { Defend the } \\
\text { solution }\end{array}$ & $\begin{array}{l}\text { Present the } \\
\text { conceptual model }\end{array}$ & $\begin{array}{l}\text { Argue to defend } \\
\text { your claim or } \\
\text { refute others' }\end{array}$ \\
\hline $\begin{array}{l}\text { Provide access to } \\
\text { the old or new } \\
\text { situations }\end{array}$ & $\begin{array}{l}\text { Try new experiment } \\
\text { when available }\end{array}$ & $\begin{array}{l}\text { Apply results } \\
\text { Make predictions }\end{array}$ & $\begin{array}{l}\text { Restart concept } \\
\text { learning cycle }\end{array}$ & $\begin{array}{l}\text { Restart cycle to } \\
\text { reach to the } \\
\text { main-claim }\end{array}$ \\
\hline
\end{tabular}

\section{Application Results and Discussion}

Köroğlu (2009) applied the model for a quasi experimental research with four groups. First group studied the topic in scaffolded simulation plus being taught about the argument structures. Second group studied only in scaffolded simulation. Third group studied in no-scaffolded simulation version. Fourth group is taught by teacher lecturing. Model progression strategy was constant for simulation version. Academic success and reasoning writings is assessed the end of learning process.

Argumentation+scaffolded simulation and only scaffolded simulation groups (compared to nonscaffolded simulation group and lectured group) were more successful on knowledge test but also on argument text (especially on claim, warrant support, consistency, warrant (causal connectionsreasoning) and holistic total). 
No significant difference is found between argumentation+scaffolded and only scaffolded simulation group except data. Although model is taught in very short time, argumentation+scaffolded group was better than other three groups on data. Perhaps this group knew that it would be a stronger argument when they present related sections of examples as evidence. Scaffolded group and non-scaffolded simulation groups had equal means on data. Both group analyzed example situations in simulation. But scaffolded group was better than lecturing group. That may prove reflecting in addition to analyzing example situations in scaffolded simulations implicitly effected the data use in reasoning text.

Another interesting result was about the rebuttal. There was no statistically significant result between any of the groups. Which make us consider question scaffolds in comparing original hypothesis to data or controlling for rebuttal did not work well. There is a couple of explanation for that result. Student did not know that they have to consider rebuttal in their writing outside the simulation. In that case transferring did not happen because argumentative or persuasive writing is not taught even in expository argumentation group. If this is the cause, a short introductory persuasive writing lesson may solve the problem. Another explanation is that actually this result may happen to be compatible with avoiding disconfirming evidence bias. Not utilizing discrepant events or non-examples adequately may leave students more vulnerable to avoiding disconfirming evidence.

Another finding of this research, there was no significant difference between non-scaffolded simulation and lecturing group (except claim and academic success). In other word, even non-scaffolded simulation group has better multiple-choice test scores then lecturing group. However, non-scaffolded group mean was lower than the scaffolded simulation groups on claim, warrant, warrant support, consistency and academic success. Only in data structure, there was no difference between noscaffolded and scaffolded simulation groups.

We have three possible cases in here. Student learns better in clasically designed simulation environment than in traditional class teaching (in terms of multiple choice responses). This result is in contrast with some of research conclusion. A model progression was a constant strategy for all simulation versions in this study. Thus, first possible conclusion can be that student learns better with a design-based simulation than in-class teaching. That result may prove the positive effect of model progression strategy and exposure to the examples in discovery format than lecturing. Since same content analysis and examples are used in expository teaching. A second possible conclusion, however; simply experimenting in simple simulation does not support the development of reasoning skills. Experimenting in simulation should be supported with appropriate scaffolding structures. A third possible conclusion is that success on academic knowledge test and explicitly stating the consistent comprehensive explanations are different kind of constructs. That may verify classical multiple choice knowledge test are not the most apropriate evaluation tools for cognitive reasoning and explanation.

There was no significant difference among none of the groups on rebuttal. Mazur (2004) recommended analyzing learners discourse, protocol, or conversation analysis to reveal patterns of conceptualization and to assess conceptual change. Below a students recording to question prompts is given.

CASE: Ahmet and Mehmet are identical twins who are separated at birth. Ahmet grows up in the poorest family in another city. Mehmet grows up in the richest family of the town.

Simulasyon-Question Prompt: When they are 20 years old, do they have different heights and kilos?

Student response: YES. Because one is rich and other is poor. The rich one will be taller and overweight. The poor one will be slim and shorter.

Simulasyon-Question Prompt: What result did you have after running the simulation?

Student response: As a result of malnutrition, height might be shorter than it is suppose to be. Malnutrition also can cause to being too slim or too fat. 
Simulasyon-Question Prompt: Is there a difference between your original opinion and the one after running the simulation?

Student response: Yes

Simulasyon-Question Prompt: Could you explain further?

Student response: It was similar but not the same. We thought the poor will be shorter and too slim. However, malnutrition may also cause slimness and shortness. We overlooked that.

With comparison-scaffold, students are asked to define whether there is any difference between their original opinion (prediction before experimenting) and later opinion (results arrived at after analyzing simulated experiment). This question prompt seems to work when there is an agreement between students' first prediction and observation result of their experiment, or when there is a total contrast between them. In above example, student arrived at the correct result after manipulating variables. Then student combined new proposition with his/her original proposition. Conceptualization did not resulted in cognitive conflict in this example. There is no sign of conflict detected by student. Student seems to attain, to some extent, an application of a rule or an essential attribute of concept in a problem context (environmental condition interacts with genetic traits). Based on piagetian model (Smith, diSessa, \& Roschelle, 1993; Siegler, 1996), we could superficially conclude that student gradually accommodated existing knowledge structure into a more coherent and better organized knowledge structures.

In reality, student failed to recognize a flaw in their thinking. First, arriving at a right conclusion was good part; however, later they had difficulty in dropping off their original non-scientific opinion. This is a clear example of inflexible discovery behavior, not being able to change original claim in the face of different findings. Combining with tendency of looking for information to confirm the hypothesis or avoiding designing experiments to disconfirm the hypotheses; inadaptability may result in students not developing scientifically consistent conceptual models or not developing scientific discovery skills, even in a scaffolded simulation environment. Although students acknowledged the difference between their first hypotheses and what they observed in experiment; in a simple simulation environment with quite few variables to manipulate; students in above example did not question or feel that they should question their first claim.

Therefore, we might follow a different path after having an answer "No" to the comparison scaffold. Presenting non-examples as in classical view of concept learning may not solve this problem. Student has to feel cognitive conflict (Strike and Postner, 1985) in order to recognize the inconsistency in their personal beliefs and presuppositions (Vosniadou, 1994). Using discrepant events may solve the issue partly. But it may not always bring totally personal theories out in the open to be questioned.

To solve this problem in scaffolding context, we could ask directly student to question their first original opinion in another note-frame, in the case of "NO" answer. Beside we have to consider this problem in relation with rebuttal component. In the study of Köroğlu (2009), there was no significant difference among experimental group means on the use of rebuttal component. This finding proves that another instructional strategy should be activated specifically for rebuttal use. In simulation, we could present example of flawed thinking or flawed experiments, then ask students to critically analyze weak arguments; then, present their rebuttal. Furthermore, socio-cultural theories of education and dialectical argumentation theories rather than critical thinking or reasoning in isolation might give us stronger base to develop other scaffold strategies. 


\section{Summary}

A Toulmin argumentation structures transformed into reasoning scaffolds for development of structured simulation environment in Genetic Unit of 8th grade of middle school. Scientific discovery learning approach seems to be working better with the regulative process through scaffolds and recording facilities. Scaffolding students reasoning in simulation environment is an advisable strategy for supporting conceptual development. However, results of model application indicate a problem on the rebuttal structure. Precursory analysis of student recordings shows that they are taking a surface approach of combining alternative hypothesis instead of questioning it. But we may also be facing only a transferring problem since we analyzed the students writing after unit completion. To figure out the essence of problem, analysis of interview transcripts and students written records is recommended for further study. It would be more helpful to add a short argumentative or persuasive writing module. Discrepant event or non-examples might be utilized more in conceptual discovery learning simulations, for creating a cognitive conflict and getting learner attention to the rebuttal factor of reasoning. To some extend, we can force students to recognize alternative hypothesis, and to work on overcoming confirmation bias by discrepant event, and non-examples. However, these strategies may solve the problem when student feel and identify the conflict. Otherwise, a more knowledgable peer or a teacher has to interfere with an appropriate question, hint or feedback. Model progression is also an advisable strategy. In this design-based research, we could conclude that reasoning scaffold model as well as Genetic Unit of 8th grade of middle school scaffolded simulation environment was very successful in fostering conceptual development of students. 


\section{Geniş Özet}

\section{Giriş}

Eğitim örgütlerinde meydana gelen etik ve hukuk dışı davranışlar son yıllarda kamuoyunun dikkatini Buluşla-Kavram öğrenme için bir simülasyon modeli tasarlanmıştır. Modelin uygulaması için 8. Sınıf Genetik Ünitesinde kullanılmak üzere simülasyonlar içeren bir öğretim yazılımı geliştirilmiştir. Simulasyonun denenmesi süreci, uygulama sonuçları ve öneriler sunulmuştur.

\section{Kavram Oluşturma}

Kavramlar nesne, olay veya diğer varlıkların bilişsel gösterimleridir (Jonassen, 2006). Kavramlar: adlarına, ayırtedici olan veya ayırtedici olmayan özelliklerine, kavramı kendisi yapan öz-nitelik değerlerine göre tanımlanır (Joyce ve Weil, 1996). Soyut ve somut olarak sınıflanabilen kavramların, hiyerarşik olarak düzenlenmesi de mümkündür (Gagne, Briggs ve Wager, 1992). Öz-nitelik değerleri, bir kavramın doğru olarak sınıflandırılmasını sağlarlar (Joyce, Weil ve Calhoun, 2000) ve özellikle soyut kavramların tanımlanmasında daha önemlidirler (Lasley, Matczynski ve Rowley, 2002). Öğrencilerin kavramları tam olarak öğrenmeleri için öğretimde kavrama örnek olanlar kadar örnek olmayanların da sunulması gereklidir (Karataş-Coşkun, 2011).

Bu tanımlamalar kavramla ilgili klasik öğretim tasarımı bakışını yansıtmaktadır. Klasik bakışta kavram, öğrenme ürünüdür. Jonassen (2006) klasik yaklaşımları eleştirerek, kuram-temelli ve etkinlik temelli yaklaşımlara dikkatimizi çekmektedir. Örneğin Kelly'nin Kişisel-Yapı Kuramı, kavramları zaman, bağlam ve amaca göre değişebilen dinamik yapılar olarak tanımlamaktadır (Kelly, 1963). Kuram-temelli ve etkinlik temelli yaklaşımlar, öğretimde olay ve nesneler arasındaki dinamik ilişkilerin kurulmasını destekleyecek ortamları teşvik ederler. Kavramlar kişiye aittir ve kişinin deneyimleri temelinde düzenlenirler.

Öğretmenler kavram öğretiminde açık veya örtük öğretimi (Akbulut-Taş, 2010) tercih edebilecekleri gibi tümevarımsal veya tümdengelimsel (Rieber ve Parley, 1995) öğretim yaklaşım ve tekniklerini tercih edebilirler. Doğrudan-tümdengelimsel (deductive) öğretim yaklaşımı, sınıflamanın vurgulandığı klasik yaklaşımlarla daha uyumlu görünmektedir. Bazı işlemsel veya süreçsel becerilerin öğretiminde daha verimli olabilirler. Tümevarımsal (inductive) yaklaşımlar ise buluş yoluna dolayısıyla daha dinamik olan kuram temelli ve etkinlik temelli yaklaşımlarla uyumludurlar. Lasley, Matczynski ve Rowley, (2002) kavram öğretiminde başarılı olan 3 tümevarımsal yaklaşım sunmuştur: illki kavram edinimi modelidir (Bruner, Goodnow ve Austin, 1967; Joyce, Weil ve Calhoun, 2000; Eggen ve Kauchak, 2001). Bu modelde öğrenciler, örneklerin ayırtedici özelliklerine ilişkin kurdukları hipotezleri test ederek ilerlerler. İkincisi kendi ürettikleri veriler üstünde eleştirel düşündükleri soruşturma modelidir (Biben, 1980). Üçüncüsü ise öğrencilerin kendi düşüncelerini ve bakış açılarını daha çok inceleyebilecekleri kavram şekillendirmedir.

Bu çalışmada Toulmin Tartışma Modeli, sokratik teknik, tümevarımsal öğretim yaklaşımı, simülasyonla öğrenme, bilimsel-buluş yoluyla öğrenme, kavram öğrenme ilişkilendirilmiştir. Simulasyonla öğrenme için bir model geliştirilmiş, modelin uygulama sonuçları kısaca tartışılmıştır.

\section{Toulmin Tartışma Kuramı}

Klasik mantık alanı argümanların geçerli olup olmadıkları ile ilgilenmektedir. Kavram öğretiminde kavramın doğru öğrenilip öğrenilmediğini değerlendirirken, öğrenenin gerekçeli açıklamasının veya tepkilerinin belirlenen sınırlar içinde geçerli olup olmadığına bakarız. Oysa günlük tartışmalarımızda argümanları değerlendirmek için güvenirliğe bakarız. Evrensel kabul edilen kurallar, ilkeler yerine 
(garanti-warrant), kendi inanç ve varsayımlarımızı öne çıkarırız. Eldeki durumdan (veri-data) hızlıca sonuca ulaşırız (iddia-claim). Bu haliyle günlük tartışmalarımız Kelly’nin Kişisel Yapı Kuramı ile tutarlıdır. George Kelly (1955) Bilimci-Birey Kuramın'da ise her bireyin çevresine uyum ve kontrol için bilim adamı gibi hareket ederek, hipotezlerini test ettiğini ileri sürmüştür. Deneyimlerimizi sınıflamak için girdiğimiz bu çaba akıl yürütmelerimizin ve tartışmalarımızın yönünü belirlemektedir. Lenat (1982) farklı problemlerle karşılaştığımızda çözüm sürecinde bilgi gösterimlerimizin de farklılaştığını düşünmektedir. Shaw (1981) ise kişisel hipotezlerin doğru tahminler yürütmede kullanıldığını hatta bilişsel yapılarımızın algılanan-ihtiyaca göre değiştirildiğini ileri sürmüştür.

Bu varsayımlardan hareketle bireysel-bilişsel şemalarımızı değiştirmenin bir yolu, değiştirilmesi gereken bilişsel şemaların açığa çıkartılarak, değiştirme ihtiyacının birey tarafından algılanmasını sağlamaktır. Kuram-temelli tümevarımsal yaklaşımlar bu noktada (uygun bir yapı sağlanabilirse) klasik öğretim tasarımına dayanan doğrudan öğretim modellerinden daha etkili hale gelebilir. Kavramsal gelişim veya bilişsel yapılarımızdaki gelişme bireyseldir, süreklidir, etkindir; farklılaştırma ve bütünleştirmenin yaratıcı bir sürecidir (Kelly,1963). Öğrencinin düşüncelerini sorgulamasına teşvik etmek ve bu sorgulamayı görünür hale getirmek, öğrencinin kişisel-bilişsel şemalarını yapılandırması sürecini destekleyebileceği gibi kavrayış yanılgılarının sergilenmesini, fark edilmesini ve değiştirilmesini de sağlayabilir. Toulmin'in ve Kelly'nin kuramları zamana, bağlama, ve amaçlara göre değişebilen kişisel anlam yapılarına işaret etmeleri açısından benzer temellere sahiplerdir. Yapıcı öğrenme çevrelerinde Toulmin'in tartışma modeli bilimsel-buluş yoluyla bilgi yapılandırmada kullanılan modellerden biridir.

Toulmin'in modeli eleştiriler almasına karşın (Aldağ, 2006a; Driver, Newton, ve Osborne, 2000; Duschl, Ellenbogen, ve Erduran, 1997; Van Eemeren, Grootendorst, Henkemans, Blair vd., 1996). Günlük tartışma ve öğretim çevrelerinde kullanılan en etkili modellerden biridir (Driver, Leach, Millar ve Scott, 1996; Kelly, Druker ve Chen, 1998; Russell, 1983; Yerrick, 2000). Toulmin'in tartışma kuramı, 6 etkileşimli öğeden oluşmaktadır (Toulmin, 1958): iddia, veri, garanti birincil öğeler, destek, reddedici, niteleyici ikincil öğelerdir. Aldağ (2005a; 2006b) bu modeli öğretim ve değerlendirmedeki tutarlığın ve güvenirliğin sağlanması amacıyla doktora çalışmasında küçük değişikliklerle uyarlamıştır. Gerekli değişiklikler için eleştiri gerekçesini araştırma temelli sunmuştur (Aldağ, 2006a). Bu çalışmada ise tartışma kuramının öğeleri simülasyon içeren bir öğretim çevresinde destek yapılar olarak kullanılmak üzere uyarlanmıştır. Buluş yoluyla-kavramsal öğrenme için simülasyon tasarım modeli geliştirilmiştir. Kavram ve düşünme yapıları ile uyum sağlayacak şekilde; garanti, veri ve destek kavramlarında küçük değişiklikler yapılmıştır. Model sokratik sorgulama tekniği kullanılarak rehberle-buluş davranışı (guideded discovery) için işlevselleştirilmiştir. Tartışma kuramı öğeleri simülasyonla öğretim yazılımında öğrenmeye destekleyici yapılara dönüştürülmüştür.

\section{Destekleme Araçları}

Bilişim teknolojilerindeki gelişmeler, öğrenmeyi destekleme yapılarının bilgisayar destekli öğretim çevrelerine aktarılması ile sonuçlanmıştır. Destekleme kavramı Vygotsky'nin yakın gelişim kavramı ile kullanılmaktadır. Çocuğun kendi başına çözebileceği problem seviyesi ve bir yetişkin veya konuyu daha iyi bilen bir akranı ile çözdüğü problem seviyesi arasındaki potansiyel farka işaret etmektedir (Wertsch, 1985). Kalabalık sınıflar için veya bireysel öğrenme için, öğrencinin gelişimini destekleyecek problem çözümünü içeren yazılımlar geliştirilmiştir. Başarılı çalışmalara örnek olarak EMILE (Guzdial, 1995), Knowledge Integration Environment (KIE) (Davis ve Linn, 2000), Model-It (Jackson, Krajcik, ve Soloway, 1998; 2000) verilebilir. Kavramsal değişim çalışan araştırmacılar, bilginin kuramsal olarak yapılandırması ve bilişsel yapının değerlendirilmesi için bazı stratejiler önermişlerdir. Bu önerilerden bazıları şunlardır: öğrenci etkileşimlerinin analizi (Hogan ve Fisherkeller, 2000), yapılandırılmış görüşmeler (Southerland, Smith, ve Cummins, 2000), kavram haritaları (Edmundson, 2000), hiper metinler (Gall ve Hannafin, 1994), simülasyon (de Jong, 1991; Reigeluth ve Schwartz, 1989) ve modelleme çevreleri (diSessa, Abelson ve Ploger, 1991). Simülasyon ortamında, bilimsel-buluş ile kavramların öğrenilmesinde öğrenin nasıl destekleneceği halen çalışılmakta olan bir konudur. 


\section{Bilgisayar Simulasyonları ve Bilimsel-Buluşla Öğrenme}

Bruner'ın buluş yoluyla kavram öğrenme çalışmaları bilimsel-buluşla öğrenme yaklaşımına temel olmuştur. Bilgisayar simülasyonları kavramsal veya operasyonel (De Jong, 1991) olabileceği gibi statikdinamik, sayısal-sözel, basit-karmaşık olarak da sınıflandırılabilir (Van Joolingen ve De Jong, 1991a; Brant, Hooper, ve Sugrue, 1991; Coleman ve Randall, 1986). En basit haliyle öğrenen, simülasyon ortamında giriş değişkenlerini kontrol ederek, ardışık sonuçları gözlemler (Reigeluth ve Schwartz, 1989). Hipotezleri test eden öğrencinin süreç sonunda, simülasyondaki modele ilişkin genellemeleri (kavram, ilke vb.) keşfetmesi beklenir. Kuramsal olarak düşündüğümüzde simülasyonun kendi kendine buluşla öğrenmeye en uygun yapıcı öğrenme araçlarından birisi olması beklenir. Ancak pek çok çalışmada buluştemelli simülasyonla öğrenme ile doğrudan öğretim arasında başarı farkına rastlanmamıştır (örn. Rivers ve Vockell, 1987; Carlsen ve Andre, 1992; Chambers vd., 1994; Bangert-Drowns, Kulik, ve Kulik, 1985). Bazı çalışmalar özel öğretici yazılımların daha başarılı olduğunu göstermiştir (Rieber, 1990; Rieber ve Parmley, 1995). Buna karşın bazı çalışmalar da simülasyonla öğrenme başarılı bulunmuştur (Grimes ve Willey, 1990). Çalışma sonuçları tutarlı görünmemektedir.

Buluş temelli simülasyonlarla öğrenmenin başarısızık ile sonuçlanması pek çok nedenle açıklanabilir: hipotezin ne olduğunun veya nasıl olduğunun bilinmemesi (Njoo ve De Jong, 1993); hipotezlerle toplanan verilerin ilişkilendirilememesi (De Jong ve Van Joolingen, 1998); hipoteze aykırı görünen verilerin gözardı edilmesi (Chinn ve Brewer, 1993); hipotezi çürüten verilere rağmen hipotezin gerçekliğinde ısrar edilmesi (ya da tersi) (Dunbar, 1993); reddedilmesi olasılığı yüksek görünen hipotezlerden (ve test edilmesinden) kaçınmak (Klayman ve Ha, 1987; Klahr, Fay, ve Dunbar, 1993; van Joolingen ve de Jong, 1993); özellikle hipotezi doğrulayacak verilerin aranması (doğrulama yanılgısı) (Quinn ve Alessi, 1993); bir denemede birden fazla değişkenin denenmesi (Glaser vd., 1992); hipotezle hiç ilgisi olmayan deneylerin yapılması (Van Joolingen ve De Jong (1991b; 1993); bir dizi değişkeni birkaç kez denerken en önemli değişkenlerin gözden kaçırılması (Kuhn, Schauble, ve Garcia-Milla, 1992); deneylerin hipotezi test etmek veya kavramsal modeli anlamaya çalışmak yerine istenen sonuca ulaşmak veya istenen etkiyi yaratmak için yapılması (mühendislik yaklaşımı) (Schauble, Glaser, Raghavan ve Reiner, 1991) gibi. Simulasyon ortamındaki öğrenmelerde başarııılık nedeni bunlardan biri veya birkaçı olabilir. Aynı simülasyon da bile öğrenenden öğrenene göre nedenler farklılaşabilir. Hatta aynı simulasyon da aynı öğrenen için bir kavramdan diğerine öğrenme düzeyi ve öğrenememe nedenleri farklılaşabilir.

Bazı çalışmalarda, buluş yoluyla öğrenmede başarılı olan ve olmayan öğrencileri ayırteden özelliğin düzenleme süreçleri olduğu belirlenmiş̧ir (Lavoie ve Good, 1988; Simmons ve Lunetta, 1993; Shute ve Glaser, 1990, Glaser vd., 1992). Sistematik planlama, izleme, veri yönetimi, verilere gerçekçi yaklaşım, not alma (Lavoie ve Good, 1988), sistematik veri kaydetme (Schauble vd., 1991) iyi bir buluşçunun özellikleri olarak tanımlanmışır. De Jong ve Van Joolingen (1998) öğrencilerin simülasyonla öğrenmelerini destekleyecek öğretim stratejileri önermişlerdir. Simülasyonla birlikte alan bilgisine ulaşılabilmesi; simülasyonların, oyun, soru, alıştırma gibi stratejilerle desteklenmesi; karmaşık durumlarda ilerleme modelinin seçilmesi; simülasyonun diğer strateji birleşimleri ile kullanılması bu önerilerden bazılarıdır. Ancak araştırmacılar hipotez desteği, deney ipuçları, gözlem destek araçları, tahmin desteği gibi stratejilerin işe yarayıp yaramayacağının araştırııması gerektiğini bildirmişlerdir.

\section{Tasarım Süreci}


Illk aşamada klasik kavram öğeleri Toulmin modelindeki tartışma öğeleri ile uyumlu duruma getirilmiştir. Aşamalar bu başlık altında tablolaştırılmıştır (Tablo1). Buluşla öğrenmede, öğrenenin temel görevleri, problemin tanımlanması, hipotezin belirlenmesi, deney kurulumu, gözlem, veri toplama, veriyi yorumlama, sonuçların denenmesi ve tahminde bulunmadır (Friedler, Nachmias ve Linn,1990). Ikinci aşamada buluşla öğrenme modeline göre akış şemaları (Şekil 1a,b) hazırlanmıştır. Literatürde öğrenme desteği olmayan karmaşık simülasyonların öğrenme yanılgıları oluşturulacağı belirtilmiştir (Hannafin ve Land, 2000). Sınıf içinde öğrencinin ön-öğrenmelerinin ve deneyimlerinin açığa çıkarılması için başarılı öğretmenlerin en sık başvurdukları teknik soru sormadır. Kavram yapıları doğrultusunda ikinci aşamada buluşla öğrenme sürecine uyumlu hale getirilen tartışma öğeleri; üçüncü aşamada, sokratik sorgulama tekniği kullanılarak, simülasyonda öğrenenin akıl yürütmesine rehber olabilecek sorular haline dönüştürülmüştür. Bu dönüştürme aşağıdaki tabloda verilmektedir. Öğrenciler simülasyonda sorulan sorulara cevap verip, cevaplarını kaydetmek, kontrol etmek ve çalışma sonunda hipotezleri doğrultusunda ikna edici bir metin hazırlamakla sorumludurlar. Destekli simülasyon (Şekil $1 \mathrm{~b}$ ) ve desteksiz simulaşyonlar (Şekil 1a) için hazırlanmış olan akış şemaları makale sonunda verilmiştir. Rehber soru örnekleri ise yine makale sonunda verilen yazılım sayfası (Şekil 2a,b,c) örneğinden incelenebilir. Toulmin'in tartışma kuramının bilimsel-buluş yoluyla öğrenmeye uyarlandığı modelin uygulanması için 8 . Sınıf genetik ünitesi seçilmiştir. Bu ünite kavram yanılgılarının yaygın olduğu literatür de belirtildiği için seçilmiştir (Schonfeld, 2000; Ferrari, Michelene ve Chi, 1998). Ünite için simülasyon hazırlanmıştır. Süreç ve yazılım genetik konusunda uzman olan iki kişi tarafından değerlendirilmiştir. Pilot çalışmalar sonunda simülasyonda gerekli düzenlemeler yapılarak, puanlama rehberi hazırlanmıştır. Puanlama rehberi ile uygulama sonrası öğrencilerin metinleri bağımsız kodlamacılar tarafından kodlanmıştır, güvenirlik oldukça yüksektir.

\section{Uygulama Sonuçları ve Tartışma}

Köroğlu (2009) modeli 8. Sınıfların genetik ünitesi için geliştirmiş olduğu simülasyona uygulamıştır. Deneysel çalışmada 4 grup vardır: 1. Grup Öğretmenle öğrenen grup; 2 . Grup klasik öğretim tasarımına göre hazırlanan simülasyonla öğrenen grup; 3. Grup modelin uygulandığı tartışma öğeleri destekli simülasyon ile öğrenen grup; 4. Grup modelin uygulandığı tartışma öğeleri destekli simülasyonla öğrenen aynı zamanda kısa tartışma öğeleri öğretimi yapılan grup. Gruplar başarı testi ve ikna edici-akıl yürütme yazıları ile değerlendirilmiştir. Yazılar tartışma öğeleri temelinde iki bağımsız kodlamacı tarafından incelenmiştir. Modelin uygulandığı simülasyon versiyonları ile öğrenim gören 3 . ve 4. Grupların, klasik simülasyon ve öğretmenle öğrenen 1. Ve 2. gruplardan her iki değerlendirmede de (tartışma öğelerinin kullanımında) daha başarılı olduğu görülmüştür. 4. Grup, veri öğesininde 3. Gruptan da başarılıdır. Araştırma sonucu, modelin uygulandığı, desteklenmiş simülasyonların öğrenmede çok etkili olduğunu göstermektedir. Bu çalışmada, reddedici (çürütme) öğesinde gruplar arasında fark bulunmamıştır. Bunun nedeni, reddedicinin öğretiminde destekli-simulasyonun başarılı olamadığı şeklinde yorumlanabilir. Başka bir açıklama ise literatürde sık sık söz edilen, hipotezi çürüten, hipoteze aykırı olan kanıt veya kuralın görmezden gelinmesi (avoiding disconfirming evidence) eğilimi olabilir. Bu durumda sorun daha fazla örnek olmayanların kullanılması ile çözülemeyecektir. Modelin uygulandığı simülasyon çalışmalarına ek olarak, tartışma ve ikna edici bilimsel-yazma çalışmaları (reddedici öğesinin vurgulandığı) faydalı olacaktır. Aykırı-uyumsuz durumlar (discrepant events) ile öğrenciye hipotezi çürüten kanıtı görmezden gelme eğilimini farketmeyi ve kontrol etmeyi öğretmek gereklidir. Aykırı durumlar, kavramlar arası farklılar ve benzerlikleri içermeli; değişkenlerin birbirleri ile etkileşimlerinin gözlenmesini ve ifade edilmesini sağlamalıdır. Ama daha da önemlisi aykırı durum öğrenenin kavrayışındaki boşluğu farketmesini ve sorgulamasını sağlayacak güdüleme mekanizmalarını harekete geçirecek nitelikte olmalıdır.

Tümevarımsal öğrenme yaklaşımı veya buluş yoluyla öğrenme stratejilerini temel alan karmaşık simülasyonların kavrayış yanılgıları yaratabileceği belirtilmiştir. Yapıcı öğrenme çevreleri ile uyumlu olan 
kuram temelli ve etkinlik temelli kavram gelişim yaklaşımlarına göre, öğrenen durumları kişisel-kuramları ve deneyimleri ile algılar, açıklar ve tepki verir. Bu nedenle yeni öğrenmeler için hali hazırda mevcut veya gelişebilecek olan kavrayış yanılgılarının görünür hale getirilmesi gerekmektedir. Buluş yoluyla kavramsal gelişimin desteklenmesi için Toulmin tartışma modeli, sokratik sorgulama tekniği ile simülasyon yapısına uygulanmıştır. Gözlem ve gözlenenlerin yansıtılmasında model ve modelin uygulandığı simülasyon oldukça başarılıdır. Yönlendirici sorular vasıtasıyla öğrenenin kendi kişisel-kuramsal yapısını açığa çıkarması ve yeni öğrendikleri ile birleştirmesi sağlanmıştır. Bu çalışma şemaların bireyselliğinin öğretim tasarımı için sınırlılık olmaktan nasıl çıkarabiliriz sorusuna cevap aramıştır. Ek olarak bilimsel-ikna edici yazma çalışmaları önerilebilir.

Tablo 1.

Simulasyonla Öğrenme için Akıl Yürütme Destek Yapıları Modeli

\begin{tabular}{|c|c|c|c|c|}
\hline Yazılım Yapısı & $\begin{array}{l}\text { Öğrenci: Akıl } \\
\text { yürütme }\end{array}$ & Buluş Süreci & Kavram Yapıları & Toulmin Modeli \\
\hline $\begin{array}{l}\text { Problemin metin } \\
\text { halinde sunulması, } \\
\text { gerekli veya uygun } \\
\text { olduğunda metnin } \\
\text { görselle desteklenmesi }\end{array}$ & $\begin{array}{l}\text { Verilen durumda neler } \\
\text { olduğunu veya neler } \\
\text { olmadığını okuma, } \\
\text { farketme, anlama }\end{array}$ & $\begin{array}{l}\text { Problemin } \\
\text { tanımlanması }\end{array}$ & $\begin{array}{l}\text { Soyut kavramın örnek } \\
\text { olanı veya örnek } \\
\text { olmayanı }\end{array}$ & Verinin sunulması \\
\hline $\begin{array}{l}\text { Verilen durumdaki } \\
\text { ilişkisel veya nedensel } \\
\text { öğelerin neler olduğunu } \\
\text { sorulması }\end{array}$ & $\begin{array}{l}\text { Ögrencinin deney } \\
\text { öncesinde verilen } \\
\text { durumla ilgili } \\
\text { tahminde bulunması }\end{array}$ & $\begin{array}{l}\text { Hipotezin ifade } \\
\text { edilmesi }\end{array}$ & $\begin{array}{l}\text { Örnek durumda } \\
\text { durumla ilgili } \\
\text { kavramların veya } \\
\text { kavramlarla ilgili } \\
\text { niteliklerin tahmin } \\
\text { edilmesi }\end{array}$ & $\begin{array}{l}\text { Alt-iddialara } \\
\text { ulaştırabilecek, veriyi } \\
\text { destekleyen } \\
\text { garantilerin ve } \\
\text { desteklerin } \\
\text { tanımlanması }\end{array}$ \\
\hline $\begin{array}{l}\text { Simulasyonun } \\
\text { sunulması }\end{array}$ & $\begin{array}{l}\text { Simulasyonda } \\
\text { manipüle edilecek } \\
\text { değişkenlerin } \\
\text { incelenmesi }\end{array}$ & $\begin{array}{l}\text { Deneyin } \\
\text { tasarlanması } \\
\text { Değişkenlerin } \\
\text { kontrol edilmesi }\end{array}$ & $\begin{array}{l}\text { Değişkenlerin verilen } \\
\text { örnekte tespiti }\end{array}$ & $\begin{array}{l}\text { Verideki değişkenlerin } \\
\text { kontrol edilmesi }\end{array}$ \\
\hline $\begin{array}{r}\text { Simulasyonun } \\
\text { başlatılması }\end{array}$ & $\begin{array}{l}\text { Deneyle ilgili notların } \\
\text { alınması }\end{array}$ & $\begin{array}{l}\text { Gözle } \\
\text { Veri toplanması } \\
\text { Verinin incelenmesi }\end{array}$ & $\begin{array}{l}\text { Sonuca doğru örnek } \\
\text { durumun veya örnek } \\
\text { olmayan durumun } \\
\text { açklanması }\end{array}$ & $\begin{array}{l}\text { İddiaya yönelten veri } \\
\text { ve reddedicilerin } \\
\text { saptanması }\end{array}$ \\
\hline $\begin{array}{l}\text { Simulasyon öncesi } \\
\text { tahminler ile } \\
\text { simülasyonda izlenenin } \\
\text { farklı olup olmadığının } \\
\text { belirlenmesi }\end{array}$ & $\begin{array}{l}\text { Hipotez ile gözlem } \\
\text { sonuçlarının } \\
\text { karşılaştırılması }\end{array}$ & Yorumlama & $\begin{array}{l}\text { Olası yanılgıların, } \\
\text { uzlaşmzlığın veya } \\
\text { ilgisiz özelliklerin } \\
\text { tespiti }\end{array}$ & $\begin{array}{l}\text { Olası reddedicilerin } \\
\text { tespiti ve } \\
\text { tutarsızlıkların } \\
\text { incelenmesi }\end{array}$ \\
\hline $\begin{array}{l}\text { Benzerlik ve farklılıklarla } \\
\text { ilgili ek açıklama } \\
\text { istenmesi }\end{array}$ & $\begin{array}{l}\text { Gerekli olduğunda } \\
\text { orijinal hipotezin } \\
\text { düzenlenmesi veya } \\
\text { yeni bir hipoteze } \\
\text { dönüştürülmesi }\end{array}$ & Yorumlama & $\begin{array}{l}\text { Akıl yürütmenin tutarlı } \\
\text { bir kavramsal model } \\
\text { oluşturmak için } \\
\text { netleştirilmesi }\end{array}$ & $\begin{array}{l}\text { Reddedicilerin kontrol } \\
\text { edilmesi, veri, garanti, } \\
\text { destekler ve iddia } \\
\text { arasındaki bağların } \\
\text { akıl yürütme yolu ile } \\
\text { kurulması }\end{array}$ \\
\hline $\begin{array}{l}\text { Orijinal veya alternatif } \\
\text { hipotezlerle ile ilgili } \\
\text { çözümlerin yazılı şekilde } \\
\text { sunulması }\end{array}$ & $\begin{array}{l}\text { Kavramsal anlayış } \\
\text { temelinde çözüme } \\
\text { ulaşma }\end{array}$ & Yorumlama & $\begin{array}{l}\text { Durumla ilgili tutarlı } \\
\text { (veya kısmen) } \\
\text { kavramsal modele } \\
\text { ulaşma: dengeleme }\end{array}$ & $\begin{array}{l}\text { Güçlü alt-iddialar, } \\
\text { veri, destek ve } \\
\text { garantilerin } \\
\text { oluşturulması }\end{array}$ \\
\hline Sınıf tartışması & $\begin{array}{l}\text { Kavramsal anlayışın } \\
\text { savunulması }\end{array}$ & $\begin{array}{l}\text { Çözümün } \\
\text { savunulması }\end{array}$ & $\begin{array}{l}\text { Kavramsal modelin } \\
\text { sunulması }\end{array}$ & $\begin{array}{l}\text { İddianın savunulması } \\
\text { ve karşıt görüşün } \\
\text { çürütülmesi }\end{array}$ \\
\hline $\begin{array}{l}\text { Yeni ve eski durumlara } \\
\text { ulaşmanın sağlanması }\end{array}$ & $\begin{array}{l}\text { Uygun olduğunda yeni } \\
\text { deneyler denenmesi }\end{array}$ & $\begin{array}{l}\text { Sonuçların } \\
\text { uygulanması Yeni } \\
\text { tahminlerin } \\
\text { yapılması }\end{array}$ & $\begin{array}{l}\text { Kavram öğrenme } \\
\text { döngüsünün yeniden } \\
\text { başlatılması }\end{array}$ & $\begin{array}{l}\text { Yeni iddialara ulaşma } \\
\text { döngüsünün } \\
\text { başlatılması }\end{array}$ \\
\hline
\end{tabular}


Habibe ALDAĞ, Ahmet DOĞANAY, L.Sema K.ULUTAŞ - Çukurova Üniversitesi Eğitim Fakültesi Dergisi, 44(1), 2015, 143-169

\section{Referances}

Aldağ, H. (2005a). The Effects of Textual ant Graphical-Textual Argumentation Software As Cognitive Tools on Development of Argumentation Skills. Unpublished doctoral thesis. Çukurova University, Adana-Turkey

Aldag, H. (2005b). Problems in university students' argumentative writing ant text analysis, Biltek International Informatics Congress, 10-12 June, 2005, Eskişehir. Turkey.

Aldağ, H. (2006a). Toulmin Tartışma Modeli. Ç.Ü. Sosyal Bilimler Enstitüsü Dergisi, Cilt 15, Sayı 1, s.13-34

Aldag, H. \& Doganay A. (2006b). The Effects of Textual ant Graphical-Textual Argumentation Software As Cognitive Tools on Development of Argumentation Skills, 6th International Conference on Argumentation of the International Society for the Study of Argumentation (ISSA), 27-30 June, University of Amsterdam-Holland

Akbulut-Taş, M. (2010). The effect of explicit instruction ant implicit learning of concept ant generalization structure on the classification ant explanation behavior, retention of the classification ant explanation behavior ant transfer. Unpublished doctoral thesis. Çukurova University-Turkey

Bangert-Drowns, R., Kulik, J., \& Kulik, C. (1985). Effectiveness of computer-based education in secondary schools. Journal of Computer Based Instruction, 12, 59-68.

Biben, R.F. (1980). Using inquiry effectively. Theory into Practice 19(2), 87-92.

Brant, G., Hooper, E., \& Sugrue, B. (1991). Which comes first the simulation or the lecture? Journal of Educational Computing Research, 7, 469-481.

Bruner, J.S. (1961). The act of discovery. Harvard Educational Review, 31, 21-32.

Bruner J.S., Goodnow, G.G., \& Austin, G. A. (1967). A study of Thinking. New York, NY: Science Edition.

Carlsen, D.D., \& Andre, T. (1992). Use of a microcomputer simulation and conceptualchange text to overcome students preconceptions about electric circuits. Journal of Computer-Based Instruction, 19, 105-109.

Carr, C. S. (1999). The effect of computer-supported collaborative argumentation (CSCA) on argumentation skills in second-year law student. Unpublished doctoral dissertation, The Pennsylvania State University, Pennsylvania.

Chambers, S.K., Haselhuhn, C., Andre, T., Mayberry, C., Wellington, S., Krafka, A., Volmer, J., \& Berger, J. (1994, April). The acquisition of a scientific understanding of electricity: Hands-on versus computer simulation experience; conceptual change versus didactic text. Paper presented at the Annual Meeting of the American Educational Research Association, New Orleans, LA.

Chinn, C.A., \& Brewer, W.F. (1993). The role of anomalous data in knowledge acquisition: A theoretical framework and implications for science instruction. Review of Educational Research, 63, 1-51.

Cho, Kyoo-Lak (2001). The effects of argumentation scaffols on argumentation and problem solving in an online colloborative problem solving environment. Unpublished Doctoral Dissertation. The Pennsylvania State University, Pennsylvania.

Coleman, T.G., \& Randall, J.E. (1986).Human-pc: A comprehensive physiological model [Computer software]. Jackson: University of Mississippi Medical Center.

Davis, E. A., \& Linn, M. C. (2000). Scaffolding students' knowledge integration: Prompts for reflection in KIE. International Journal of Science Education, 22(8), 819-837. 
Habibe ALDAĞ, Ahmet DOĞANAY, L.Sema K.ULUTAŞ - Çukurova Üniversitesi Eğitim Fakültesi Dergisi, 44(1), 2015, 143-169

de Jong, T. (1991). Learning and instruction with computer simulations. Education \& Computing, 6, 217229.

de Jong, T. \& van Joolingen, W.R. (1998) Scientific discovery learning with computer simulations of conceptual domain, Journal Review of Educational Research, 68 (2), 179-202

diSessa, A., Abelson, H., \& Ploger, D. (1991). An overview of Boxer. Journal of Mathematical Behavior, 10, 3-15.

Driver, R., J. Leach, R. Millar, \& P. Scott (1996). Young's People Images Of Science, Buckingham: Open University Pres.

Driver, R., P.Newton, \& J.Osborne (2000). Establishing the norms of scientific argumentation in classroom, Science Education, 20, 1059-1073.

Dunbar, K. (1993). Concept discovery in a scientific domain. Cognitive Science, 17, 397-434.

Duschl, R. A., K. Ellenbogen, \& S. Erduran (1997). Promoting argumentation in middle school science classrooms: A Project SEPIA evaluation. The Annual Meeting of the National Association of Research in Science Teaching.

Edmundson, K.M. (2000). Assessing science understanding through concept maps. In J. J. Mintzes, J. H. Wandersee, J. D. Novak (Eds.), Assessing science understanding: A human constructivist view (pp. 19-40). San Diego: Academic Press.

Eggen \& Kauchak (2001). Strategies for Teacher. (4th ed)Needham Heights, MA: Alyn and Bacon.

Ferrari, M. and Michelene T. H. Chi (1998), The nature of naive explanations of natural selection, Learning Research and Development Center, University of Pittsburgh, USA.

Friedler, Y., Nachmias, R., \& Linn, M.C. (1990). Learning scientific reasoning skills in microcomputerbased laboratories. Journal of Research in Science Teaching, 27, 173-191.

Gagne, R.M., Briggs, L. J., \& Walter, W.W. (1992) Principles of instructional design (4th. ed.). New York, NY: Harcourt Brace Jovanovich

Gall, J. \& Hannafin, M. (1994). A framework for the study of hypertext. Instructional Science,. 22, 207232.

Ge, X. \& Land, S.M. (2003), Scaffolding Students' Problem-Solving Processes in an II-Structured Task Using Question Prompts and Peer Interactions, ETR\&D, 51(1), 2003, pp. 21-38.

Ge, X., \& Land, S. M. (2004). A conceptual framework for scaffolding II-structured problem-solving processes using question prompts and peer interactions. Educational Technology Research and Development, 52(2), 5-22.

Schauble, L., Glaser, R., Raghavan, K., \& Reiner, M. (1991). Causal models and experimentation strategies in scientific reasoning. Journal of the Learning Sciences, 1 (2), 201-238.

Grimes, P.W. \& Willey, T.E. (1990). The effectiveness of microcomputer simulations in the principles of economics course. Computers and Education, 14, 81-86.

Guzdial, M. (1995). Software-realized scaffolding to facilitate programming for science learning. Interactive Learning Environments, 4(1), 1-44.

Hannafin, M.J. \& Land S.M. (2000). Technology and student-centered learning in higher education: issues and Practice, Journal of Higher Education, 12(1), 3-30 
Habibe ALDAĞ, Ahmet DOĞANAY, L.Sema K.ULUTAŞ - Çukurova Üniversitesi Eğitim Fakültesi Dergisi, 44(1), 2015, 143-169

Hogan, K., \& Fisherkeller, J. (2000). Dialogue as data: Assessing students' scientific reasoning with interactive protocols. In J. J. Mintzes, J. D. Novak, \& J. W. Wandersee (Eds.), Assessing science understanding: A human constructivist view (pp. 96-124). San Diego, CA: Academic Press.

Jackson, S. L., Krajcik, J., \& Soloway, E. (1998). The Design of Guided Learning-Adaptable Scaffolding inlnteractive Learning Environments. Human Factors in Computing Systems: $\mathrm{CHI}$ '98 Conference Proceedings, Los Angeles.

Jonassen, D. H. (2006). On the role of concepts in learning and instructionaldesign. Educational Technology research and Development, 54(2), 177-196.

Joyce, B., Weil, M. \& Calhoun, E. (2000). Models of Teaching (6th ed) Boston: Allyn and Bacon

Karataş-Coşkun, M. (2011). Kavram Öğretimi. Karahan Kitabevi, Adana-Turkey

Kelly, G.A. (1955). The Psychology of Personal Constructs. Norton. New York,

Kelly, G. A (1963) . A Theory of Personality. Norton, NewYork.

Kelly, G. J., S. Druker, \& C. Chen, (1998). Students' reasoning about electiricity: combining performance assessments with argumentation analysis. International Journal of Science Education, 20, 849-872.

Klahr, D., Fay, A.L., \& Dunbar, K. (1993). Heuristics for scientific experimentation: A developmental study. Cognitive Psychology, 25, 111-146.

Klayman, J., \& Ha, Y-W. (1987). Confirmation, disconfirmation, and information in hypothesis testing. Psychological Review, 94, 211-228.

Kuhn, D., Schauble, L., \& Garcia-Mila, M. (1992). Cross-domain development of scientific reasoning. Cognition and Instruction, 9, 285-327.

Köroğlu (2009). The effect of argumentation scaffolds in simulation on academic success and argumentation structures-use in the 8th grade genetic unit. Unpublished master thesis. Çukurova University, Adana-Turkey.

Lasley II, T.j., Matczynski, T.J., \& Rowley, J. B. (2002). Instructional Models: Strategies for Teaching in a Diverse Society. Belmon, CA: Wadsworth/Thomson Learning.

Lavoie, D.R., \& Good, R. (1988). The nature and use of predictions skills in a biological computer simulation. Journal of Research in Science Teaching, 25, 335-360.

Lenat, D. B. (1982) Heuretics: Theoretical and Experimental Study of Heuristic Rules. AAAl, 159-163

Lunsford, K. J. (2002). Contextualizing Toulmin's model in the writing classroom: a case study. Written Communication 19(1), 76-109.

Mazur, J. M. (2004). Conversation analysis for educational technologists: theoretical and methodological issues for researching the structures, processes and meaning of online talk. In D. H. Jonassen (Ed.), Handbook of Research on Educational Communications and Technology. Mahwah, NJ: Lawrence Erlbaum Associates.

Merill, M.D. (1983). Componet display theory. In C. M. Reigeluth (Ed.),Instructional Design Theories and Models: An Overview of Their Current Status. Hillsdale, NJ: Lawrence Erlbaum Associates

Ferrari, M. \& Chi, M.T.H. (1998). The nature of naive explanations of natural selection. International Journal of Science Education,20(10), 1231-1256

Njoo, M., \& de Jong, T. (1993). Exploratory learning with a computer simulation for control theory: Learning processes and instructional support. Journal of Research in Science Teaching, 30, 821-844. 
Habibe ALDAĞ, Ahmet DOĞANAY, L.Sema K.ULUTAŞ - Çukurova Üniversitesi Eğitim Fakültesi Dergisi, 44(1), 2015, 143-169

Reigeluth, C.M., \& Schwartz, E. (1989). An instructional theory for the design of computer-based simulations. Journal of Computer-Based Instruction, 16, 1-10.

Rieber, L.P. (1990). Using computer animated graphics in science instruction with children. Journal of Educational Psychology, 82, 135-140.

Rieber, L.P., \& Parmley, M.W. (1995). To teach or not to teach? Comparing the use of computer-based simulations in deductive versus inductive approaches to learning with adults in science. Journal of Educational Computing Research, 14, 359-

Rivers, R. H., \& Vockell, E. (1987). Computer simulations to stimulate scientific problem solving. Journal of Research in Science Teaching, 24, 403-415.

Russell, T. L. (1983). Analyzing arguments in science classroom discourse: Can teachers' questions distort scientific authority," Journal of Research in Science Teaching, 20, 27-45.

Schauble, L., Glaser, R., Raghavan, K., \& Reiner, M. (1991). Causal models and experimentation strategies in scientific reasoning. The Journal of the Learning Sciences, 1, 201-239.

Schonfeld, D. (2000). Teaching Evolution in Secondary Schools: Historical Context, Social Concerns, and Stumbling Blocks, Department of Education, Kalamazoo College Kalamazoo, Michigan.

Shaw, M. L. G. (1981). Recent Advances in Personal Construct Technology. London: Academic Press.

Shute, V.J., \& Glaser, R. (1990). A large-scale evaluation of an intelligent discovery world: Smithtown. Interactive Learning Environments, 1, 51-77.

Simmons, P.E., \& Lunetta, V.N. (1993). Problem-solving behaviors during a genetics computer simulation: beyond the expert/novice dichotomy. Journal of Research in Science Teaching, 30, 153173.

Southerland, S. A., Smith, M. U ., \&Cummins, C. L. (2000). "What do you mean by that?" Using Structured Interviews to Assess Science Understanding. In J. J. Mintzes, J. H. Wandersee, \& J. P. Novak (Eds)., Assessing science understanding: A human constructivist view. (Chapter 6). Academic Press.

Strike, K. A. \& Posner, G. J. (1985) A conceptual change view of learning and understanding in L.H.T. West, A.L. Pines (Eds.), Cognitive structure and conceptual change, Academic Press, New York

Quinn, J. \& Alessi, S.M. (1993, April). The effects of simulation complexity and hypothesis generation strategy on learning. Paper presented at the annual meeting of the American Educational Research Association, Atlanta, GA.

Tan, S. C. (2000), Supporting collaborative problem solving trough computersupported colloborative argumentation. Unpublished Doctoral Dissertation. The Pennsylvania State University, Pennsylvania.

Tennyson, R. D. \& Park, O. C. (1980) The teaching of concepts: a review of instructional design research literature Review of Educational Research, 50: 55-70

Toulmin, S. (1958). The Uses of Argument. Cambridge, UK: Cambridge University Press.

Toulmin, S. E., R. D. Rieke, \& A. Janik (1984). An Introduction To Reasoning (2. Ed.), New York, NY: Macmillan.

Van Eemeren, F. H., R. Grootendorst, F. S. Henkemans, J. A. Blair, R. H. Johnson, E. C. W. Krabbe, C. Plantin, D. N. Walton, C. A. Willard, J. Woods, \& D. Zarefsky (1996). Fundementals of Argumentation 
Habibe ALDAĞ, Ahmet DOĞANAY, L.Sema K.ULUTAŞ - Çukurova Üniversitesi Eğitim Fakültesi Dergisi, 44(1), 2015, 143-169

Theory: A Handbook of Historical Backgrounds and Contemporary Developments, Mahwah: Lawrence Erlbaum Associates.

Van Joolingen, W.R., \& De Jong, T. (1991a). Characteristics of simulations for instructional settings. Education \& Computing, 6, 241-262.

van Joolingen, W.R., \& De Jong, T. (1991b). Supporting hypothesis generation by learners exploring an interactive computer simulation. Instructional Science, 20, 389-404.

Van Joolingen, W.R., \& De Jong, T. (1993). Exploring a domain through a computer simulation: traversing variable and relation space with the help of a hypothesis scratchpad. In D. Towne, T. de Jong \& H. Spada (Eds.), Simulation-based experiential learning (pp. 191-206). Berlin, Germany: Springer-Verlag.

Wertsch, J.V. (1985). Cultural, Communication, and Cognition: Vygotskian Perspectives. Cambridge University Press.

Yerrick, R.K. (2000). Lower torch science students' argumentation and open inquiry instruction. Journal of Research in Science Teaching, 37, 807-838.A 


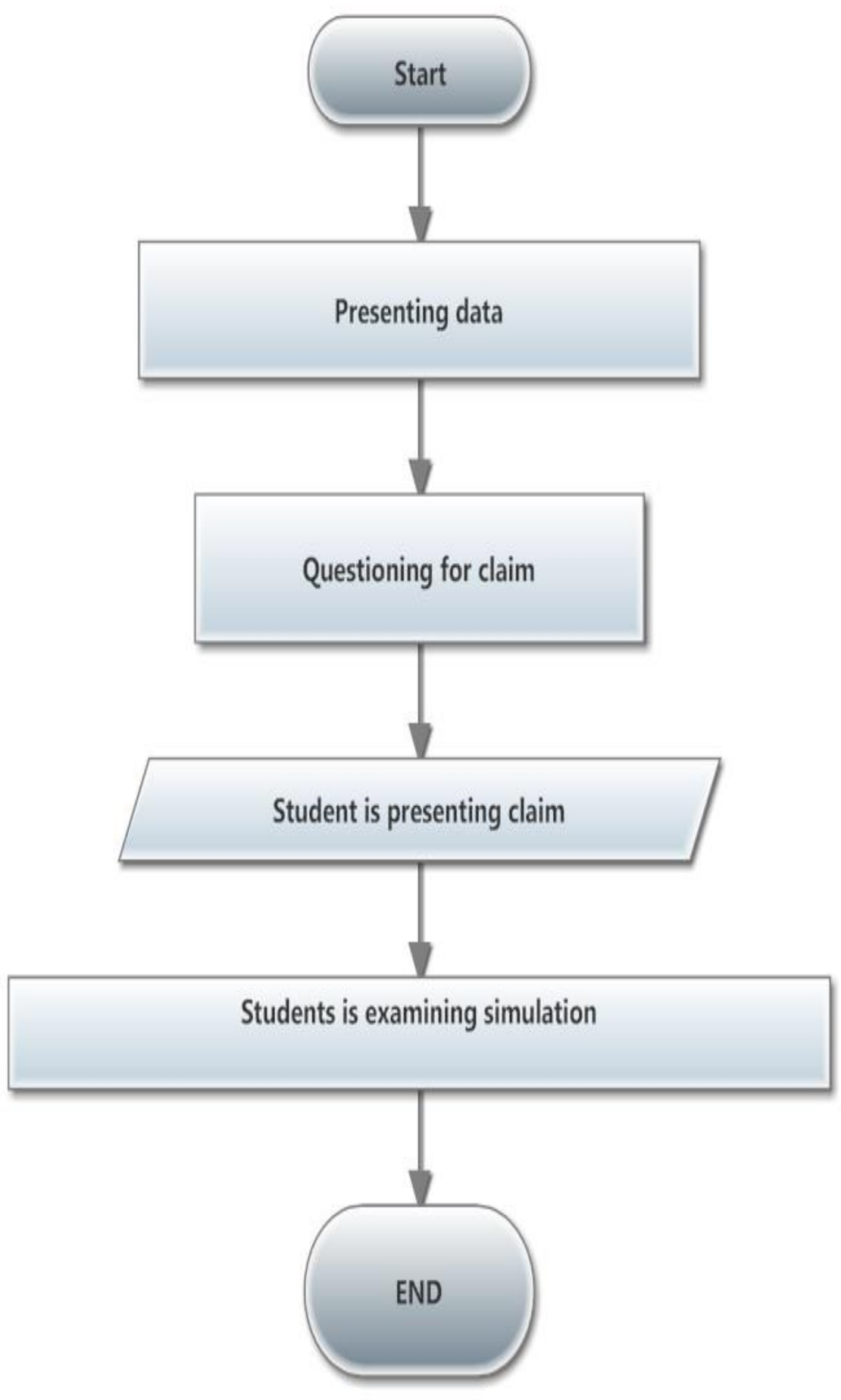

Figure 1.a Flowchart for nonscaffolded-simulation 
Habibe ALDAĞ, Ahmet DOĞANAY, L.Sema K.ULUTAŞ - Çukurova Üniversitesi Eğitim Fakültesi Dergisi, 44(1), 2015, 143-169

A Flowchart of Reasoning Scaffold Model for Instructional Simulation/Software

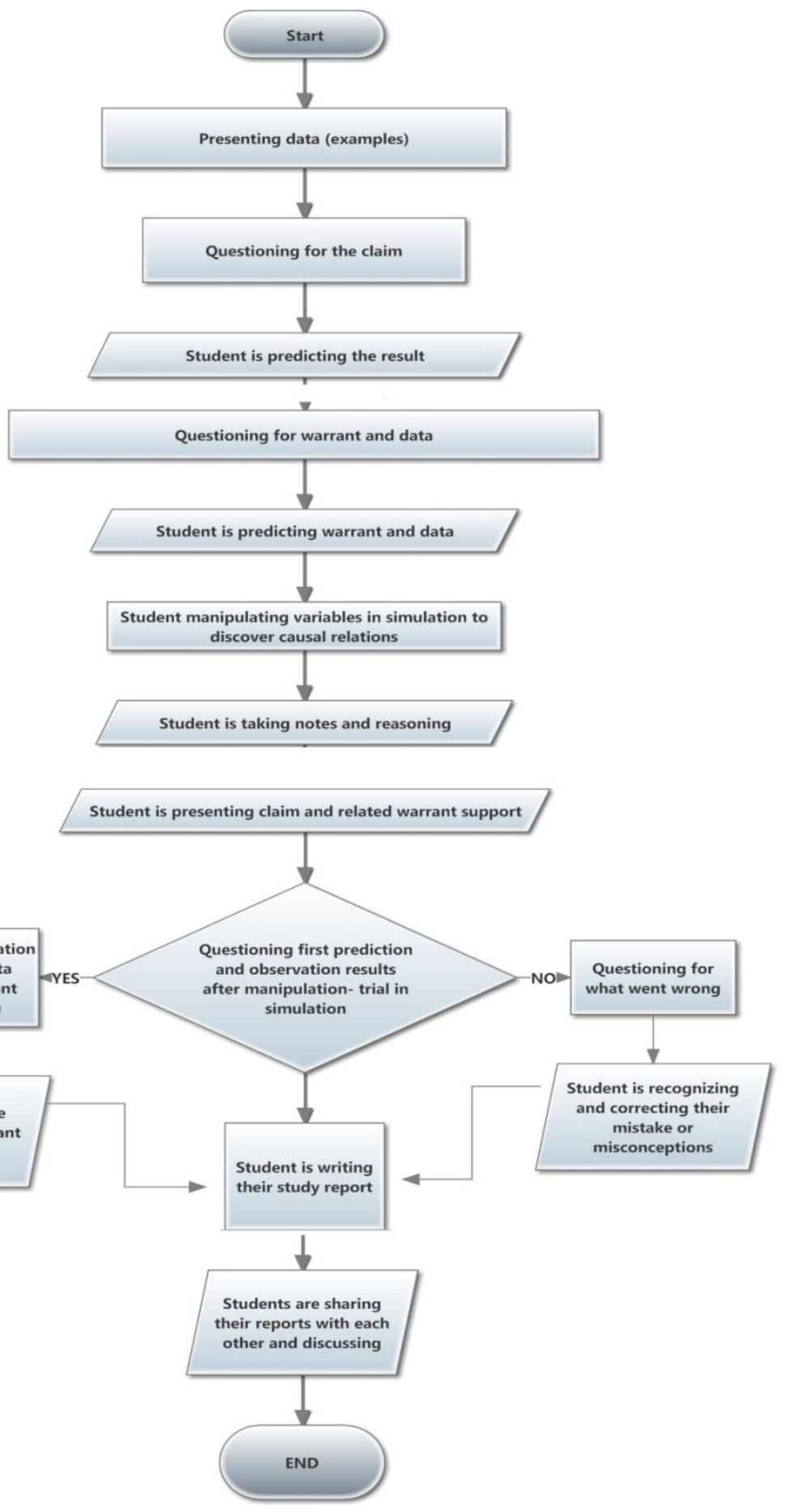

Figure 1.b Flowchart for scaffolded simulation 
Habibe ALDAĞ, Ahmet DOĞANAY, L.Sema K.ULUTAŞ - Çukurova Üniversitesi Eğitim Fakültesi Dergisi, 44(1), 2015, 143-169

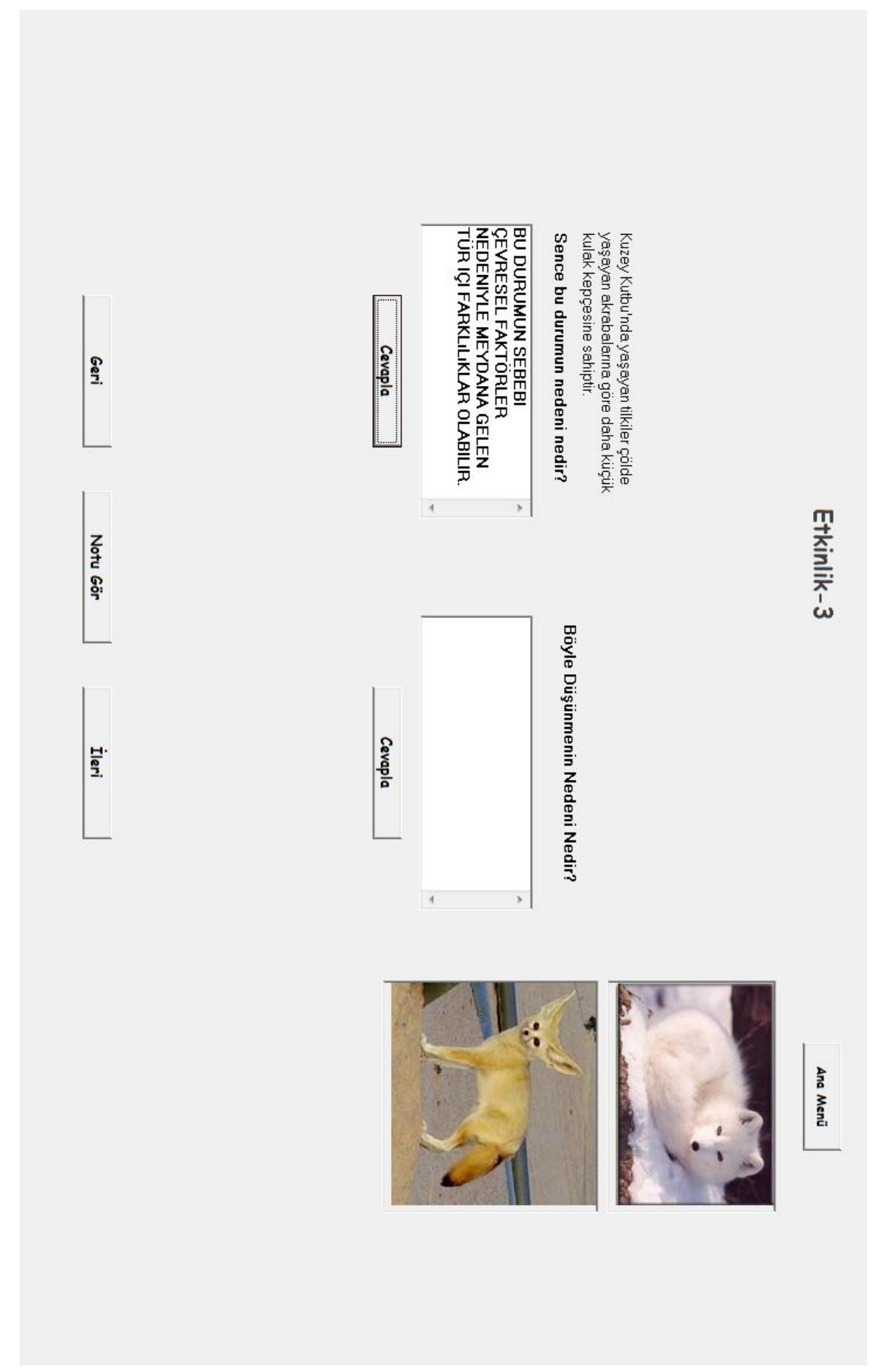

Figure 2.a Simulation page: Question prompts 

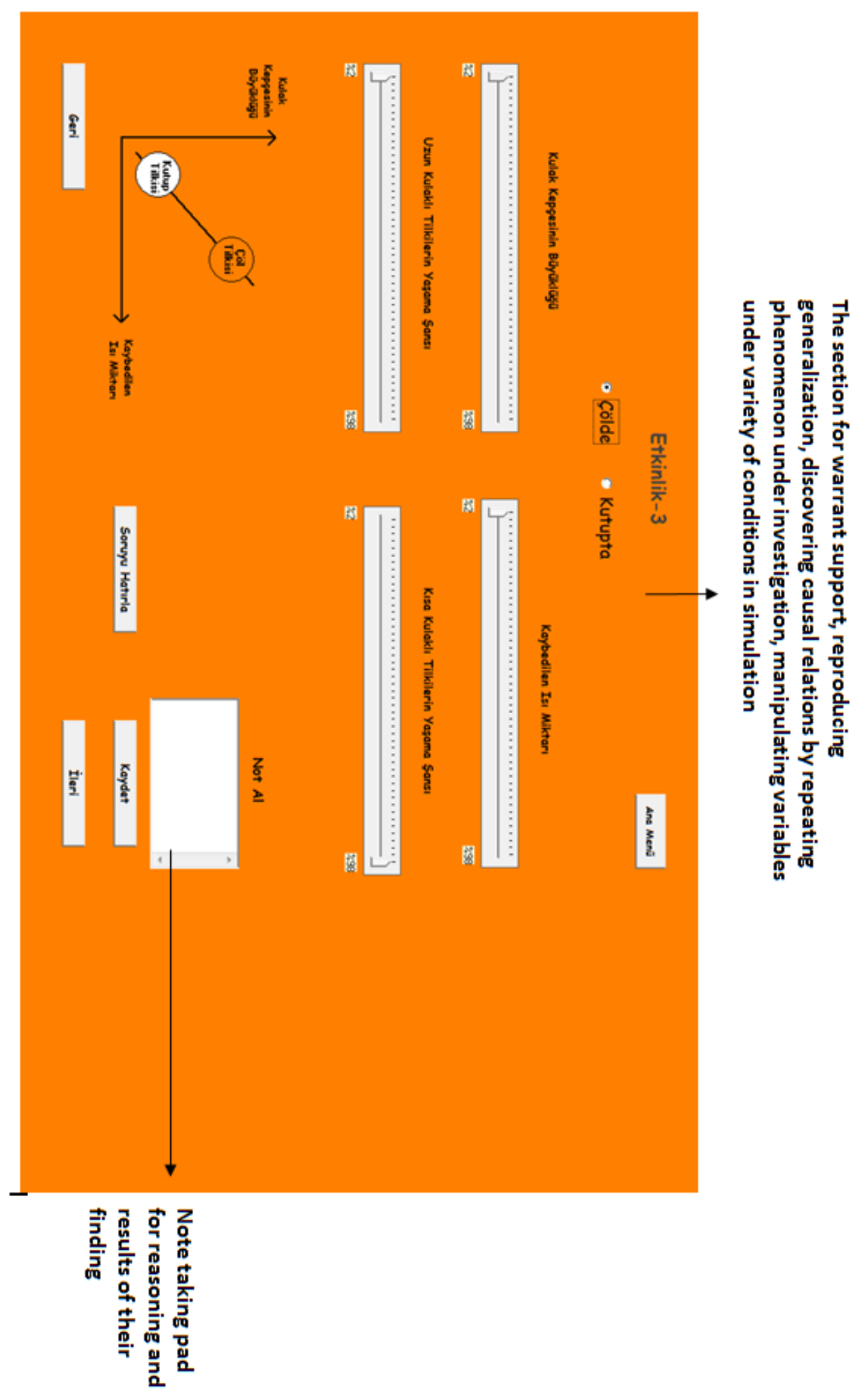

Figure 2.b Simulation page: Question prompts 




Figure 2.c Simulation page: Question prompts 